\title{
Water Pricing and Affordability in the US: Public vs Private Ownership
}

\author{
Xue Zhang ${ }^{1, *}$, Marcela González Rivas ${ }^{2}$, Mary Grant ${ }^{3}$, Mildred E. Warner ${ }^{1}$
}

Cornell Working Paper, posted to SocArXiv, June 2021

${ }^{1}$ Cornell University, Department of City and Regional Planning, Ithaca, NY, USA

2. University of Pittsburg, Graduate School of Public and Int'l Affairs, Pittsburgh, PA, USA

3. Food \& Water Watch and Food \& Water Action, Baltimore, MD, USA

* Corresponding author:

Xue Zhang

316 W. Sibley, Ithaca, NY, USA

607-379-7618

xz435@cornell.edu

ORCID

Xue Zhang: https://orcid.org/0000-0002-5786-4235

Marcela González Rivas: https://orcid.org/0000-0002-4311-4409

Mildred E. Warner: https://orcid.org/0000-0002-0109-338X

Acknowledgements:

This work is funded in part with support from the Atkinson Center for Sustainable Futures at Cornell University. 


\title{
Water Pricing and Affordability in the US: Public vs Private Ownership
}

\begin{abstract}
We examine the 500 largest community water systems in the US to explore if ownership is related to annual water bills and the percent of income that low-income households spend on water. Results show that, among the largest water systems, private ownership is related to higher water prices and less affordability for low-income families. In states with regulations favorable to private providers, water utilities charge even higher prices. Affordability issues are more severe in communities with higher poverty and older infrastructure. Water policy needs to address ownership and regulation and explore new mechanisms to ensure water affordability for low-income residents.
\end{abstract}

Key words: water pricing, water affordability, privatization, state regulation, poverty

\section{Introduction}

Water affordability is becoming a widespread water challenge in the US (Jones \& Moulton, 2016; Mack \& Wrase 2017; Walton, 2015). Recent reports about the affordability crisis in water access in the US argue this is particularly important for low income and minority communities, which tend to be disproportionately affected by increasing water bills (Lakhani, 2020; Mack \& Wrase, 2017; NAACP, 2019; Swain et al., 2020). There is a general misconception that water and sanitation challenges pertain mainly to the Global South (González Gómez, García-Rubio \& Guardiola, 2020; Martins et al, 2016), but there is growing awareness of the challenges faced in the global north.

Water rates vary across countries and even within regions of the same country (Hoque \& Wichelns, 2013, Zetland \& Gasson, 2013) and scholars have analyzed the variety of factors that influence or determine water rates (David, et al., 2014; González-Gómez et al., 2018; Wait \& 
Petrie, 2017). One of them is ownership structure, which is the focus of our paper. Specifically, is there a significant difference in water rates across private and public water utilities? While some studies show that privately owned water utilities charge higher prices for water (Beecher \& Kalmbach, 2013; Wait \& Petrie, 2017), others find no difference between public and private operators (Bel, Fageda \& Warner, 2010). There is a longstanding and contentious debate about water privatization (Tortajada, et al., 2013), and water rate pricing is one of the central factors in that debate.

Our study builds upon previous studies examining factors related to water pricing and affordability for community water systems in the US (Beecher \& Kalmbach, 2013; Wait \& Petrie, 2017). Aside from comprehensive representation (including the entire universe of large water systems in the US), our study expands the analysis in the following ways: we are interested if ownership can differentiate water rates (the annual water bill for a typical household) and affordability (the percent low-income families spend on water). We also are interested if water price and affordability vary by state regulatory environment (regulation favorable to private providers), age of water infrastructure and community socioeconomic conditions (poverty, race).

\section{Literature review}

Our analysis builds on previous studies comparing water rates across public and private water utilities, including factors that have been considered relevant in the literature as important determinants of water rates (Barbosa \& Brusca, 2015; García-Valiñas et al., 2013; Reuster \& Zschille, 2010; Romano, et al, 2015; Saal \& Parker, 2001; Wait \& Petrie, 2017). One factor studied in the literature, and the focus of this paper, is ownership structure. The empirical evidence is not conclusive. For example, García-Valiñas et al. (2013) distinguish between three types of ownership structure in Spain and find the lowest prices are in local publicly owned 
utilities. Barbosa and Brusca (2015) also find that privately owned utilities in Brazil charge higher prices, even when utilities are under local and regional regulatory agencies' price mechanisms. However, Romano et al. (2015) find no difference between public and private utilities in Italy. A study found that privately owned utilities in Germany charge higher prices and this is explained by higher investment (Reuster \& Zschille, 2010), but Saal and Parker (2001) find that it is not investment but rather profit seeking what drives higher prices among private operators in the UK.

The importance of ownership structure in water provision has been widely discussed in the literature. One argument is that privately owned utilities might be more efficient than public ones. The argument behind the efficiency of privately owned water utilities being able to deliver similar service at lower costs is based on the idea that profit maximization drives the incentive for efficient allocation of resources and cost reduction, an incentive that may be lacking for public utilities (Rubenstein, 2000). However, others have argued that the same idea of profit maximization drives privately owned utilities to seek rate increases, as they try to maximize their rates (Lobina \& Hall, 2000; Lobina, 2005; Romano \& Guerrini, 2014). There are empirical studies across the world supporting both arguments, but a meta regression analysis finds no statistical support for lower costs with private water operators (Bel et al., 2010). Other studies find there is no conclusive evidence that sets one ownership structure superior to the other (Abbott \& Cohen 2009; Bel \& Warner 2008; Renzetti \& Dupont 2003; Tortajada et al., 2013). This could be due to close regulation of quality and pricing by water operators through EPA standards and state Public Utility Commissions. This would prevent reductions in quality to enhance profits - theoretically expected of for-profit operators by property rights theory (Hart, Shleifer \& Vishny, 1997). However, with a natural monopoly such as water, problems with 
information asymmetry make it difficult to structure contracts. This is why Megginson (2005), who generally supports privatization in other sectors, recommends water should not be privatized. Other studies explore the relationship between prices charged by privately owned utilities and their exposure to competition, as observed in contract renewals (Chong et al., 2006) or "benchmark" competition within the same localities (Walsten \& Kosec, 2005). We must distinguish competition for the market from competition in the market (Bel \& Warner, 2008). As a natural monopoly there is generally no competition in water service delivery at the local level.

As a natural monopoly, water requires careful regulation to ensure quality and avoid excessive pricing, but also requires attention to issues related to the environment, public health and equity (Cotta, 2012; de Gouvello \& Scott, 2012). The regulatory framework is a key factor that influences water rates and other water policies (Megdal, 2012; Owen, 2013). For example, Bel et al. (2013), in a comparison of privatization of water services across two regions in Spain, find that the institutional capacity of regional regulatory agencies is central for protecting the interests of users. More specifically to the US, a study of the role of public vs private sector for water management in Arizona (Megdal, 2012) argues that the state regulatory commission and local bodies can have significant implications for water utility practices regarding investments, water conservation and other policies. These in turn can have an effect on rates.

In the US, states play an important role in water utility rate regulation. Public and private utilities are regulated differently. Private utilities are regulated by Public Utility Commissions (PUCs) in forty-five states (Beecher, 2019) and public water utilities are regulated by PUCs in six states (Environmental Finance Center, 2017). Water quality is regulated in all utilities, both public and private. The level of regulation or the proximity of the regulator to the utility can 
lower costs of enforcing contracts (Beecher, 2009; Troesken \& Geddes, 2003). In the US, according to the 2012 International City County Management survey, most municipal water utilities are municipally owned (Homsy \& Warner, 2014). According to the US EPA's Safe Drinking Water Information System (2021), among the very large community water systems (serving more than 100,000 people), most are owned by local governments. But as large investor-owned utilities such as American Water and Essential Utilities' Aqua America have grown in the US market, they have pushed for more regulatory favorability through surcharges, such as Distribution System Improvement Charges (DSIC) (which pass capital improvement costs directly on to ratepayers to enable rate hikes in between rate case review), "fair value" legislation $^{1}$ (valuing a water system asset above the book value), and other mechanisms that facilitate investor earnings and acquisitions (American Water, 2015; Caffrey, 2020; Janney Capital Markets, 2013; Lynch, 2015). Pennsylvania and New Jersey, which have the highest penetration of these two companies, have led the way in many of these pro-private regulatory changes (Caffrey, 2020; Janney Capital Markets, 2013; Kline, 2018).

There are many other factors, besides ownership, that might affect water rates: size, source of water, age of system, etc. (comprehensive reviews of the factors affecting water prices include González-Gomez \& García-Rubio, 2018, Zetlan \& Gasson, 2013). The size of the utility may make a difference in water pricing because of economies of scale (Carvalho, Margues, \& Berg, 2012). Larger utilities can reduce costs of operation through their ability to obtain cheaper prices for larger orders for inputs and materials given their size. For example, scale economies help explain higher levels of efficiency in water utilities in Portugal (Correia \& Marques, 2011). But, in the case of investor owned utilities, whether these savings get passed on to ratepayers in lower prices depends on whether they get passed on to shareholders as profit instead. 
Water prices also are affected by infrastructure system conditions and age, which in the US has been a decades long challenge (ASCE 2021). In the US, federal funding for water sector infrastructure has been declining since the mid-1970s (Congressional Budget Office, 2015; University of North Carolina, 2015). This decline, combined with increased demands for meeting water quality and environmental compliance, has often resulted in increasing water service rates, as utilities raise rates to modernize and maintain water systems infrastructure. In the context of limited federal funding, water rates are affected in areas where systems need new investment in upgrading, operation and maintenance (Jacobson, 2016; Mack \& Wrase, 2017; Walton, 2015). In fact, aging infrastructure is one of the key challenges across water utilities in the US, according to the 2019 Survey of the American Water Works Association (AWWA, 2019a). In response to COVID-19, the 2021 American Rescue Plan allows funding for upgrading municipal water and sewer systems (US Treasury, 2021).

Other physical characteristics affect water rates, such as topographic characteristics of the place and water source, as this has implications for the technology used and the costs incurred to access water. Water is generally classified into ground and surface water, and while both sources can provide safe drinking water, the process of treating groundwater tends to be less costly than that for surface water because, in general, it is less polluted and more reliable during drought periods (González-Gomez, et al. 2018; Howe, 2005; Safe water, 2017). Therefore, in regions where severe drought is recurrent, water utilities will incur higher costs for water production (AWWA, 2019b; Wait \& Petrie, 2017).

The characteristics of the cities where utilities operate, such as population density and population growth, can also potentially affect what water utilities charge for services, as it is more cost efficient to maintain infrastructure in areas with higher densities (Bel \& Warner, 
2008). Utilities also need to consider the costs of infrastructure maintenance and expansion in areas experiencing population growth to keep up with increasing water demand, which contributes to increasing costs (Jacobs \& Howe, 2014). By contrast, in communities with small or declining population, water systems face sunk infrastructure costs and a declining consumer base, which can also lead to higher rates (Grant, 2020; González Rivas, 2020; Jacobson, 2016; Pauli, 2020).

Other factors that capture the structural conditions of a place, such as socio-economic characteristics of the population served, are also important factors to consider. Communities with a higher percentage of poverty may face more problems in ensuring affordability (González Rivas, 2020; Lakhani, 2020; Mack \& Wrase, 2017; NAACP, 2019; Swain et al., 2020). The COVID-19 pandemic has raised attention to the need to address water affordability. During the pandemic, many states and hundreds of cities passed moratoria to prevent water disconnections for low-income households (FWW, 2020). A study of water shut off moratoriums found US cities with higher income, larger shares of people of color and higher levels of income inequality, were more likely to protect low-income consumers from water shutoff (Warner, Zhang \& González Rivas; 2020). Water affordability programs are needed to address the water access challenges of the lowest income households in the US. States, municipalities and utilities all have a role to play (Homsy \& Warner, 2020; Pierce, Chow \& DeShazo 2020; Pierce et al., 2021; Swain et al. 2020).

In the models that follow we explore these factors to assess if water rates are different in communities with public or private operators. The next section presents our data, followed by our models and results. The final section concludes. 


\section{Data}

\section{Water pricing and affordability}

We compiled the water bill information for all the 500 largest community water systems in the US for our database. Ours is the first national study to look at all of the 500 largest community water systems in the US. The 500 largest community water systems were identified based on service population, using the U.S. EPA's Safe Drinking Water Federal Information System. We used service population and location to match these utilities to the city or county where they were located. The 500 largest water systems are from 48 states and the District of Columbia and collectively serve about 140 million people (44\% of the entire US population in 2015). Private owners are more common in smaller systems (EPA 2021), but our interest is in the differences in water prices in the more complex large urban systems from which the majority of US residents receive their water.

Water price is measured by typical household annual bill. We compiled water utility rates schedules in January 2015 from utility websites, local government ordinances, or calls to the utility's customer service line. Seasonal rates were weighted to arrive at an annual average. Bills were inclusive of all water-related fees and surcharges. The estimated indoor usage of a typical U.S. family was estimated to be 60,000 gallons a year based on the standard metric of 50 gallons per person per day for indoor water usage (for example, see AWWA 2019) and the average family size of about 3.27 (US Census 2016). ${ }^{2}$

To get at water affordability, we give special attention to lower income residents. We measure water affordability as the percent of household income spent on water by the lowest quintile of household income (Colton 2005). Our annual bill and affordability data for the 500 largest water systems finds that water systems with higher annual bills are clustered in New 
Jersey, Pennsylvania, Illinois, Michigan, West Virginia and California. However, most states have at least one water system where low-income households spend more than $3 \%$ of their income on water bills. Our models explore factors related to water pricing and water affordability in terms of water system characteristics, water supply and water demand. The equations are shown below.

Water price $($ annual bill $)=\mathrm{f}$ \{ private ownership, regulation, service population, age of infrastructure, water source, level of drought, community socioeconomic factors (inequality, poverty, percent minority, population density, population growth)\}

Water affordability (percent of household income spent on water by the lowest quintile of household income $)=\mathrm{f}$ (private ownership, regulation, service population, age of infrastructure, water source, level of drought, community socioeconomic factors (inequality, poverty, percent minority, population density, population growth)\}

Water system characteristics: Ownership, Regulation and Age of Infrastructure

Our primary interest is in the difference in price and affordability by public and private water systems. We created a dummy variable to measure if the water system is owned by a private company. While there is a broader range of ownership structures in the US for smaller systems (EPA 2021), our study focuses on the largest systems, which include public (government and cooperative) and private (investor owned) utilities. Among the 500 water systems, 321 are government owned, 121 are cooperative and 58 are investor owned. In our data, water systems owned by the private sector have a significantly higher annual bill (\$501) than water systems owned by the public sector $(\$ 315)$. Low-income households also spent a higher percent of income on water if the utility is owned by the private sector $(4.39 \%)$ than if it is owned by the 
public sector $(2.84 \%)$. We expect that private ownership will be related to a higher water price and less affordability after controlling for other factors.

We also control for state regulatory structure. We created a dummy variable at the state level for states that regulate public water utilities through their Public Utility Commission (PUC). Six state PUCs regulate at least some public water systems: Indiana, Maine, Pennsylvania, Rhode Island, West Virginia, and Wisconsin. We did not control for states where the PUC regulates private operators, because all the 58 privately owned water systems in our sample are located in states where the PUC regulates private utilities. To capture states which have created regulatory policy more favorable to private operators, we create a dummy variable to control for New Jersey and Pennsylvania. PA and NJ are leaders in implementing new regulations that favor private operators (e.g. DSIC, fair market value) (Caffrey, 2020; Janney Capital Markets, 2013; Kline, 2018). Age of infrastructure could also be a factor on price. We use the percent of occupied housing built before 1940 as a proxy for older water pipelines. Older pipes will have a higher need of replacement and this would be related to higher water prices. Descriptive statistics of model variables are shown in Table 1.

\section{Water supply}

Water supply is measured by the water source and the level of drought at the county level. Among the 500 largest water systems in our data, $18 \%$ used groundwater, and $82 \%$ used surface water. We create a dummy variable to measure if the water source is groundwater. Compared to surface water, groundwater is less expensive due to less water runoff (González-Gomez, et al. 2018; Safe water, 2017). We expect that water systems using groundwater will have a lower water price and more affordability for low-income households. 
Table 1 Descriptive Statistics: Water Systems, 500 largest US Cities, 2015

\begin{tabular}{|c|c|c|c|c|c|}
\hline Variable & Obs & Mean & Std. Dev. & Min & Max \\
\hline \multicolumn{6}{|l|}{ Water price and affordability } \\
\hline Annual water bill, $\$ 1$ & 500 & 336.54 & 132.47 & 84.24 & 910.05 \\
\hline Lowest quintile of household income ${ }^{2}$ & 500 & 12840 & 5184 & 2798 & 36561 \\
\hline $\begin{array}{l}\text { Percent of household income spent on water } \\
\text { (for lowest quintile of household income) }^{1,2}\end{array}$ & 500 & 3.02 & 1.91 & 0.62 & 21.30 \\
\hline \multicolumn{6}{|l|}{ Water system } \\
\hline Private sector ${ }^{1}$ & 500 & 0.12 & 0.32 & 0 & 1 \\
\hline PUC regulates public utilities ${ }^{1,3}$ & 500 & 0.05 & 0.22 & 0 & 1 \\
\hline Favorable Private Regulation $(1=\mathrm{NJ}, \mathrm{PA})$ & 500 & 0.07 & 0.26 & 0 & 1 \\
\hline Service population $(\ln )^{1}$ & 500 & 12.14 & 0.74 & 11.36 & 15.93 \\
\hline Percent occupied houses built before $1940^{2}$ & 500 & 12.23 & 13.77 & 0.07 & 63.12 \\
\hline \multicolumn{6}{|l|}{ Water supply } \\
\hline Groundwater $(1=y e s)^{1}$ & 500 & 0.18 & 0.38 & 0 & 1 \\
\hline Severe Drought $(\%)^{4}$ & 500 & 23.75 & 38.53 & 0 & 100 \\
\hline \multicolumn{6}{|l|}{ Water demand } \\
\hline Gini $^{2}$ & 500 & 0.46 & 0.04 & 0.34 & 0.63 \\
\hline Poverty rate $^{2}$ & 500 & 17.41 & 7.43 & 2.72 & 45.80 \\
\hline Percent minority $^{2}$ & 500 & 46.37 & 20.81 & 3.40 & 98.41 \\
\hline Population density $(\ln )^{2}$ & 500 & 7.64 & 1.00 & 4.21 & 10.23 \\
\hline Population growth $(\%)^{2,6}$ & 500 & 4.12 & 3.82 & -6.52 & 25.26 \\
\hline
\end{tabular}

Data sources: 1. Our Data Base on Price of 500 Largest Water Systems 2015. 2. American Community Survey 2011-2015. 3. Beecher, 2018. 4. U.S. Drought Monitor 2015. 5. American Community Survey 2007-2011

We measure the intensity and impact of drought at the county level. Data are from the United States Drought Monitor (2015). The 500 large water systems in our database are located in 321 counties. The level of drought is measured by abnormally dry, moderate drought, severe drought, extreme drought and exceptional drought (United States Drought Monitor, 2015). We differentiate systems in counties with severe drought or higher. Twenty four percent of the 500 water systems in our sample are located in counties having severe drought or higher in 2015 . We expect that water systems located in counties with a higher percent of severe drought will have higher water rates and less affordability. 


\section{Water demand}

Water demand is measured by the number of people served by the water system, and community socioeconomic conditions. Our dataset shows among the 500 largest water systems, each system served an average of 279,946 people. We link the water system locations with county and city level data from American Community Survey (2011-2015 averages) to explore socioeconomic conditions related to water pricing and affordability. We include variables on income inequality (Gini), poverty rate, percent minority, population density, and population growth. We expect prices could be higher in both shrinking and growing communities, so we control for population growth using American Community Survey data (2011-2015 average minus 2007-2011average).

\section{Results}

We ran ordinary least squares regression models on factors related to water price and affordability controlling for ownership, regulation, water supply and community characteristics. Results are shown in Table 2.

Our model results show that, among the largest 500 water systems in the US, private ownership results in higher water prices and less affordability, after controlling for all other factors. Private ownership has the largest effect on average annual water bill of all model variables. Results show that the average annual water bill is $\$ 144$ more in the privately owned water systems than in the publicly owned water systems. Also, in the communities with privately owned water systems, low-income households spend $1.55 \%$ more of their income on their water bills. These results hold after controlling for other factors that would affect water price and affordability: regulatory environment, water supply, age of system, and community demographics. 
Table 2 Regression Results: Differences in Public and Private Water Rates, 500 largest US cities

\begin{tabular}{|c|c|c|c|c|}
\hline & \multicolumn{2}{|c|}{ Annual water bill ${ }^{1}$} & \multicolumn{2}{|c|}{$\begin{array}{l}\text { Percent of household income } \\
\text { spent on water (for lowest } \\
\text { quintile of household } \\
\text { income) })^{1,2}\end{array}$} \\
\hline & Coeff. & Std. Coeff & Coeff. & Std. Coeff \\
\hline \multicolumn{5}{|l|}{ Water system characteristics } \\
\hline Private sector ${ }^{1}$ & $144.04 * *$ & $0.35^{* *}$ & $1.55^{* *}$ & $0.26^{* *}$ \\
\hline PUC regulates public utilities ${ }^{1,3}$ & -36.43 & -0.06 & -0.29 & -0.03 \\
\hline $\begin{array}{l}\text { Favorable Private Regulation } \\
(1=\text { NJ, PA) }\end{array}$ & $88.64 * *$ & $0.17^{* *}$ & 0.46 & 0.06 \\
\hline $\begin{array}{l}\text { Percent of occupied houses built } \\
\text { before } 1940^{2}\end{array}$ & $1.35^{* *}$ & $0.14 * *$ & $0.01 *$ & $0.10^{*}$ \\
\hline \multicolumn{5}{|l|}{ Water supply } \\
\hline Groundwater $(1=y e s)^{1}$ & $-46.97 * *$ & $-0.14 * *$ & $-0.52 * *$ & $-0.10 * *$ \\
\hline Severe Drought $(\%)^{4}$ & $0.81 * *$ & $0.24 * *$ & 0.00 & 0.03 \\
\hline \multicolumn{5}{|l|}{ Water demand } \\
\hline Gini $^{2}$ & 84.08 & 0.03 & 2.64 & 0.06 \\
\hline Poverty rate ${ }^{2}$ & -1.86 & -0.10 & $0.14 * *$ & $0.55 * *$ \\
\hline Service population $(\ln )^{1}$ & -10.96 & -0.06 & $-0.20^{*}$ & $-0.08 *$ \\
\hline Percent minority $^{2}$ & -0.16 & -0.02 & -0.01 & -0.06 \\
\hline Population density $(\ln )^{2}$ & -11.04 & -0.08 & -0.07 & -0.03 \\
\hline Population growth $(\%)^{2,5}$ & -0.90 & -0.03 & -0.02 & -0.05 \\
\hline $\mathrm{N}$ & \multicolumn{2}{|c|}{500} & \multicolumn{2}{|c|}{500} \\
\hline adj. R-sq & \multicolumn{2}{|c|}{0.32} & \multicolumn{2}{|c|}{0.45} \\
\hline
\end{tabular}

$\mathrm{N}=500$ largest water utilities in the US, 2015

Data source: 1. Our Data Base on Price of 500 Largest Water Systems 2015. 2. American Community Survey 2011-2015. 3. Beecher, 2018. 4. U.S. Drought Monitor 2015. 5. American Community Survey 2007-2011

Note: $* \mathrm{p}<0.05, * * \mathrm{p}<0.0$, OLS regression results

All private systems in our sample are regulated. However, in New Jersey and Pennsylvania water regulations have become more favorable to private operators than in many other states, and our model results show this leads to higher prices in those states. Only six states regulate public systems, but this has no effect on price or affordability. This may be because publicly owned systems are directly accountable to ratepayers and do not have to pay shareholder dividends. 
Water supply and drought can affect water pricing and affordability. Model results show that community water systems using groundwater are more likely to have a lower water bill and have a lower percent of household income spent on water, as expected. Also, a higher percent of severe drought in the county where the water system is located is related to a higher annual water

bill. Age of system also matters. Water systems in communities with more housing built before 1940, have higher annual bills and are less affordable. These communities need to replace aging water pipes and this can raise costs.

We control for demographic characteristics of the community and find population size, density and growth are not related to price differences. However, water systems that serve more people are more affordable, likely due to economies of scale.

Poverty has an important effect on water affordability. Low-income households in communities with a higher poverty rate spend a larger percentage of their income on their water bills. The relation between poverty rate and household spending implies the flaws of the marketbased water price: water, as a necessary good, is not affordable for many low-income households.

\section{Discussion}

We find that public ownership is related to lower prices in the 500 largest water systems after controlling for regulation, water supply and demand. Privately owned water systems have significantly higher annual bills and are less affordable for low-income families. What might explain this difference?

Our results show regulation matters. In New Jersey and Pennsylvania, regulations are more favorable to private providers (Caffrey, 2020; Janney Capital Markets, 2013; Kline, 2018). Model results show regulatory differences in these two states leads to $\$ 89$ higher annual water 
bill in NJ and PA. By contrast, our models find no impact of regulation of publicly owned utilities on water price or affordability. This may be because publicly owned utilities have a broader interest beyond profit; they are generally interested in fair pricing and affordability to their residents (Mann \& Warner 2019; McDonald 2018). Municipally owned utilities are also more likely to protect low-income residents from water shutoff (Homsy \& Warner, 2020; Warner et al. 2020). Regarding problems with water affordability, private ownership and poverty rate are the primary drivers.

Table 3 shows data on selected states. In table 3, we see that the highest number of private systems are in California, but prices and affordability are a bigger problem in New Jersey and Pennsylvania, the states with the next highest number of private providers. State regulation appears to explain the difference. According to industry reports (Janney Capital Markets, 2013), New Jersey and Pennsylvania have more regulations more favorable to private providers and California has regulations least favorable to private providers. New Jersey and Pennsylvania are states where regulatory capture ${ }^{3}$ is found in shifts in state regulation to favor private interests over the public. For example, an American Water investor presentation (2015) described legislation in New Jersey and Pennsylvania that enabled its growth: the NJ Water Infrastructure Protection Act (N.J.S.A. 58:30-1 et seq), which allows the private purchase of municipal systems without a public referendum; and Act 11 of 2012 in Pennsylvania, which allows consolidated pricing for water and wastewater services. There were 15 new regulatory mechanisms put into place across the company's footprint from 2010 to 2015, and the company's customer acquisitions were concentrated in states that authorize the use of "fair market value" (American Water, 2016), which leads to inflated acquisition prices and no consideration of the original 
source of funds (e.g. state and federal investments) when the system is privatized. These features cede public control and lead to higher household water prices.

Michigan has a serious affordability problem, but none of the large water systems in that state are private. Table 3 shows that communities in Michigan have a higher poverty rate and on average, a decreasing population. Prices are not higher, but affordability is a major challenge. Poverty, population decline, and aging infrastructure explain the difference. Public systems have not been able to address this challenge without implementing new investment and new affordability programs (Butts \& Gasteyer, 2011; Rockowitz et al., 2018). Thus, the issue is not just private ownership and regulatory capture, but also problems of aging infrastructure, population decline and poverty in older communities. To provide adequate customer assistance and affordability programs requires state and federal water support (Pierce et al., 2021; Swain et al., 2020).

Table 3 Water system differences across states

\begin{tabular}{|c|c|c|c|c|}
\hline & California & New Jersey & Pennsylvania & Michigan \\
\hline Private sector owned $^{1}$ & 17 & 10 & 7 & 0 \\
\hline Total \# of water systems ${ }^{1}$ & 100 & 16 & 19 & 15 \\
\hline$\%$ privately owned $^{1}$ & 17 & 63 & 37 & 0 \\
\hline Annual bill \$ (average) ${ }^{1}$ & 396.85 & 433.7 & 501.2 & 324.1 \\
\hline Annual bill/low income ${ }^{1,2}$ & 2.95 & 3.69 & 4.65 & 4.1 \\
\hline Poverty rate $(\%)^{2}$ & 16.28 & 17.22 & 17.12 & 22.09 \\
\hline $\begin{array}{l}\text { Age of infrastructure (Percent of } \\
\text { occupied houses built before } 1940)^{2}\end{array}$ & 8.19 & 22.87 & 32.31 & 16.81 \\
\hline Population growth ${ }^{2,3}$ & 4.23 & 1.23 & 0.62 & -0.62 \\
\hline
\end{tabular}

Data sources: 1. Our Data Base on Price of 500 Largest Water Systems 2015. 2. American Community Survey 2011-2015. 3. American Community Survey 2007-2011

Older cities with low population growth face challenges with water system upgrading and affordability. T test results show that communities in New Jersey, Pennsylvania and Michigan have lower population growth $(0.45 \%)$ than other communities in our sample $(4.53 \%)$. While 
our initial models did not find a direct effect of population growth on price, if we drop the variables for age of infrastructure (age of housing) and favorable private regulation, then we find communities with population growth have lower water prices and more affordability (Appendix 1). Growing places can spread costs across new residential developments. Many of the communities with the highest prices are in deindustrialized places with both old infrastructure and high poverty. Addressing these problems requires a comprehensive approach.

\section{Conclusion}

Our study of the 500 largest community water systems in the US shows that privately owned systems have higher annual bills and lower affordability, consistent with previous findings in the US (Wait \& Petrie, 2018). We control for the major factors that would affect price and affordability (demand, supply and regulatory features) and this result remains. Of further concern is the issue of regulatory capture. While California has the largest number of private providers in our dataset, it has strong regulation. This helps the systems in California maintain affordability. By contrast New Jersey and Pennsylvania have the next highest levels of privatization and their prices are some of the highest in the sample. American Water and Aqua America (now called Essential Utilities), which are the largest US-based investor owned water utilities, have successfully advocated for regulatory and legislative changes that facilitate acquisitions and price increases, including "fair value" legislation and distribution system improvement charges (DSIC) to facilitate cost shifts to ratepayers (American Water, 2015; Aqua America, 2015; Caffrey 2020; Janney Capital Markets, 2013). ${ }^{4}$ These pro-private regulatory changes are spreading across the US. As of 2019, ten states had passed fair market value legislation, and this is expected to lead to more acquisitions and consolidation in the future (Beecher, 2019). As private equity becomes more involved in community water systems, they 
seek a shorter time frame for expected profits (Mann and Warner 2019, Beecher and Kalmbach 2021). This leads to higher prices and more affordability problems. While affordability is also a challenge in publicly owned systems, such as Michigan and the well documented problems in Flint and Detroit (Butts \& Gasteyer, 2011; Pauli, 2020; Rockowitz et al., 2018), our overall model results show it is private ownership and regulatory capture that primarily drive these results.

The debate over public versus private ownership of drinking water systems has focused primarily on issues of efficiency and price. Our study contributes to the growing body of literature that challenges the claimed efficiency benefits of private ownership (Bel et al., 2010; Lobina \& Hall, 2000). But as water systems age and affordability challenges rise (Gasteyer et al., 2016; Mack \& Wrase, 2017; NAACP, 2019), this creates a challenge for both public and private systems to address. Research on affordability shows that state level programs work best (Swain et al., 2020) and the importance of targeted approaches to provide ongoing bill assistance as well as shutoff protection (Pierce et al., 2021). Cities can implement percentage-of-income water affordability programs with arrears management components to reduce water bill burdens and address the water arrearages of low-income households. Baltimore and Philadelphia are examples of public systems which have water affordability programs based on income (Grant, 2020; Mack et al., 2020). In addition, the federal government has a role to play in addressing national water affordability issues by expanding grants and low-interest loans to localities through the Drinking Water and Clean Water State Revolving Loan Programs and USDA's Rural Water and Waste Disposal Loan and Grant Program. Federal funding must be prioritized to disadvantaged communities facing affordability challenges. 
One important argument regarding water tariffs is related to resource conservation in the context of increasing water demand (Pierce et al 2021; Tortajada, et al, 2016; Zetland \& Gasson, 2013). While water conservation is an important water issue, it should not be an obstacle to addressing water affordability for low-income households. There is evidence that affordability programs can also promote water conservation. For example, a recent study of Philadelphia's Tiered Assistance Program found that affordability programs based on household income in the US do not have a negative effect on water conservation efforts (Mack, et al 2020). A national study of US municipalities found that municipally owned systems were more likely to both impose conservation practices and protect consumers from water shut off (Homsy \& Warner 2020).

Some cities across the US have brought privatized systems back under public control. This remunicipalization process shows attention to a broader set of public objectives beyond price. These include attention to conservation, investment, access and local control (González Rivas, 2020; McDonald, Spronk \& Chavez, 2020; McDonald, 2018; Mann \& Warner, 2019; Rodriguez, 2004), but the challenges of affordability and investment remain (Bel, 2020; Pierce et al., 2021). The debate on water price and affordability needs to move beyond the question of ownership to issues of regulatory control and mechanisms to enhance affordability. 


\section{Endnotes}

1. "Fair value" allows an outside appraiser to set the purchase price recoverable from rates based on one of three methods: replacement cost, market value or income approach. All of these methods inflate the value above the more standard depreciated cost approach allowed by PUCs.

2. For comparison, in 2016, AWWA found average indoor water use was 58.6 gallons per capita per day, slightly higher than the usage estimate used; and 138 gallons per household per day, which was slightly lower at 50,370 gallons a year but is reflective of all households, rather than just families (AWWA 2016).

3. Regulatory capture refers to the excessive influence that private sector actors have in the process of defining rules and regulation. Regulatory capture, often referred to as the Stockholm Syndrome, is where regulators take on the interests of the regulated industry instead of those of the consumers or users, as is happening in PA and NJ with water regulations. This undermines the goal of having regulation in the first place, to prevent abusive monopoly power in the industry (Dal Bo, 2006).

4. A regulated investor-owned utility earns a rate of return based on its rate base (the investment value of its assets). Allowing a higher purchase price through "fair value" and having that be automatically included in its rate base, inflates the rate base and the total return (corporate profits) earned on that rate base. This has a dual effect of making it more profitable for companies to buy systems and making it easier to entice cities to sell because the company can offer higher purchase prices. The higher cost is recovered by raising water prices. 


\section{References}

Abbott, M., \& Cohen, B. (2009). "Productivity and Efficiency in the Water Industry." Utilities Policy 17 (3): 233-244.

American Society for Civil Engineers (ASCE) (2021). Report Card for America's Infrastructure. Retrieved from https://infrastructurereportcard.org/

American Water. (2015). Institutional Investor Presentation. January, p. 16.

American Water. (2015). Institutional Investor Presentation. December, p. 22.

American Water. (2016). Institutional Investor Presentation. October, pp. 16, 18.

Aqua America. (2015). Aqua America's (WTR) CEO Nick DeBenedictis on Q4 2014 Results Earnings Call Transcript. Seeking Alpha. February 27.

AWWA. (2016). Residential End Uses of Water, Version 2. Executive Repot, p. 5, Retrieved from https://www.awwa.org/Portals/0/AWWA/ETS/Resources/WaterConservationResidential _End_Uses_of_Water.pdf?ver=2016-04-14-14-135024-200

AWWA. (2019a). Development a New Framework for Household Water Affordability and Financial Capability Assessment in the Water Sector, p.3, Retrieved from at https://www.awwa.org/Portals/0/AWWA/Government/DevelopingNewFrameworkFor AffordabilityReport.pdf

AWWA. (2019b). State of the Water Industry Report. American Water Works Association. Retrieved from https://www.awwa.org/Portals/0/AWWA/ETS/Resources/2019_STATE\%20OF\%20THE \%20WATER\%20INDUSTRY_post.pdf (accessed March 8, 2021).

Barbosa, A., \& Brusca, I. (2015). Governance structures and their impact on tariff levels of Brazilian water and sanitation corporations. Utilities Policy, 34, 94-105. doi:10.1016/j.jup.2015.02.002

Beecher, J. (2009). Water pricing and the cost of service in the United States. Institute for Public Utilities, paper prepared for OECD, Michigan State University: Lansing, MI.

Beecher, J. (2019). Potential for economic regulation of Michigan's water sector. Michigan State University Extension. Lansing, MI.

Beecher, J. (2019). Corporate consolidation of water utilities: Is fair market value fair? Institute of Public Utilities, Michigan State University: Lansing, MI.

Beecher, J. A., \& Kalmbach, J. A. (2021) From Profit to Polity: A U.S. Water Utility's Transition to a Government-Shareholder Model, https://papers.ssrn.com/sol3/papers.cfm?abstract id=3828802

Beecher, J. A., \& Kalmbach, J. A. (2013). Structure, regulation, and pricing of water in the United States: a study of the Great Lakes region. Utilities Policy, 24, 32-47.

Bel, G. (2020). Public versus private water delivery, remunicipalization and water tariffs. Utilities Policy, 62, 100982.

Bel, G., Fadega, X., \& Warner, M. (2010). Is private production of public services cheaper than public production? A meta-regression analysis of solid waste and water services. Journal of Policy Analysis and Management, 29(3), 553-577. doi: 10.1002/pam.20509

Bel, G., \& Warner, M. (2008). Does privatization of solid waste and water services reduce costs? A review of empirical studies. Resources, Conservation and Recycling, 52(12), 13371348.

Bel, G., González-Gómez, F. \& Picazo-Tadeo, A.J. (2013). The dynamics of privatization and regulation of water services: a comparative study of two Spanish regions, International 
Journal of Water Resources Development, 29:3, 373-384,

DOI:10.1080/07900627.2012.721692

Butts, R., \& Gasteyer, S. (2011). Environmental Reviews \& Case Studies: More cost per drop: Water rates, structural inequality, and race in the United States-The case of Michigan. Environmental practice, 13(4), 386-395.

Caffrey, M. (2020). This industry's lobbying organization just moved from D.C. to Philly. Here's why. Philadelphia Business Journal. January 29.

Colton R (2005) A water affordability program for the Detroit Water and Sewerage Department (DWSD). Available at: https://detroitevictiondefense.org/resources/2005WaterAffordabilityProgram_Colton_D WSD_01062005.pdf (accessed April 23, 2021)

Congressional Budget Office. (2015). Public Spending on Transportation and Water Infrastructure, 1956 to 2014. Retrieved from https://www.cbo.gov/publication/54539.

Correia, T., \& Marques, R. C. (2011). Performance of Portuguese water utilities: how do ownership, size, diversification and vertical integration relate to efficiency?. Water Policy, 13(3), 343-361.

Chong, E., Huet, F. and Saussier, S. (2006). Auctions, Ex Post Competition and Prices: The Efficiency of Public-Private Partnerships. Annals of Public and Cooperative Economics 77 (4): 521-554.

Dal Bó, E. (2006). Regulatory capture: A review. Oxford review of economic policy, 22(2), 203225.

David, C.P.C, Cayton P. J, Lorenzo T. \& Santos E. C. Santos (2014). Statistical analysis of Philippine water district characteristics and how these affect water tariffs, Water International, 39:1, 1-9, DOI: 10.1080/02508060.2013.847687

de Gouvello B. \& Scott, C. (2012). Has water privatization peaked? The future of public water governance, Water International, 37:2, 87-90, DOI:10.1080/02508060.2012.663614

Environmental Finance Center. (2017). An Overview of Clean Water Access Challenges in the United States. Chapel Hill, NC: UNC Environmental Finance Center.

EPA. (2021). Safe Drinking Water Information System. Retrieved from https://ofmpub.epa.gov/apex/sfdw/f?p=108:200 (accessed April 21, 2021).

FWW. (2020). External-local-state water shutoff moratoriums amidst coronavirus. Database accessed April 30, 2021. https://docs.google.com/spreadsh eets/d/153Ze6RRZZZ9oVkaSErhVHGMv3Z4laQDs0GRO7UmYnQ/edit\#gid=1 796772260.

Gasteyer, SP, Lai, J, Tucker, B, Carrera, J, Moss, J. 2016. BASICS INEQUALITY: Race and Access to Complete Plumbing Facilities in the United States. Bois Rev. 13, 305-325. https://doi.org/10.1017/S1742058X16000242

García-Valiñas, M.A., Gonzalez-Gomez, F., Picazo-Tadeo, A.J., (2013). Is the price of water of residential use related to provider ownership? Empirical evidence from Spain. Utilities Policy 24 (C),56-69.

González-Gómez, F., García-Rubio, M. Á., \& Guardiola, J. (2020). Some reflections on water for residential uses in developed countries. International Journal of Water Resources Development, 36(2-3), 311-324.

González-Gómez, F., \& García-Rubio, M. A. (2018). Prices and ownership in the water urban supply: a critical review. Urban Water Journal, 15(3), 259-268. 
González Rivas, Marcela. (2020). A Tale of Two Water Operators: Legacies of Public Versus Private Amidst Covid-19 in Pittsburgh in Public Water and COVID-19: Dark Clouds and Silver Linings, Municipal Services Project (Kingston), Transnational Institute (Amsterdam) and Latin American Council of Social Sciences (CLASCO) (Buenos Aires).

Grant, M. (2020). A Beacon of Hope at a Time of Crisis? Pursuit of Affordable Public Water in Baltimore in Public Water and COVID-19: Dark Clouds and Silver Linings, Municipal Services Project (Kingston), Transnational Institute (Amsterdam) and Latin American Council of Social Sciences (CLASCO) (Buenos Aires).

Hart, O. D., Shleifer, A., \& Vishny, R. W. (1997). The proper scope of government: Theory and an application to prisons. Quarterly Journal of Economics, 112, 1127-1161.

Howe, C.W. (2005) The Functions, Impacts and Effectiveness of Water Pricing: Evidence from the United States and Canada, International Journal of Water Resources Development, 21:1, 43-53, DOI: 10.1080/0790062042000316811

Hoque, S. F. \& Wichelns, D. (2013) State-of-the-art review: designing urban water tariffs to recover costs and promote wise use, International Journal of Water Resources Development, 29:3, 472-491, DOI: 10.1080/07900627.2013.828255

Homsy, G., \& Warner, M. (2020). Does public ownership of utilities matter for local government water policies? Util Policy, 64, 101057. doi:10.1016/j.jup.2020.101057

Homsy, G., \& Warner, M. (2014). Intermunicipal Cooperation: The Growing Reform, pp 53-65 in The Municipal Yearbook 2014, Washington, DC: International City County Management Association.

Jacobs, J. W., \& Howe, C. W. (2005). Key issues and experience in US water services privatization. International Journal of Water Resources Development, 21(1), 89-98.

Jacobson J. (2016). 'Keeping the Water On: Strategies for Addressing High Increases in Water and Sewer Rates for Baltimore's Most Vulnerable Customers.' The Abell Report. 29(4), 1-28. Baltimore, Maryland, The Abell Foundation.

Janney Capital Markets (2013). Think secular, act cyclical: the pragmatist's guide to water. Equity Research Industry Report. p 55-57. November 13.

Jones, P. \& Moulton, A. (2016). The invisible water unaffordability in the United States. Unitarian Universalist Service Committee. http://www.uusc.org/sites/default/files/water_report_july_2016_update.pdf

Kline, K.J. (2018). Water Distribution System Improvement Charges: A Review of Practices, Report No. 18-01, National Regulatory Research Institute, Washington, DC.

Lakhani, N. (2020). Revealed: millions of Americans can't afford water as bills rise 80\% in a decade. The Guardian. Retrieved from: https://www.theguardian.com/usnews/2020/jun/23/millions-of-americans-cant-afford-water-bills-rise

Lobina, E. (2005). Problems with private water concessions: a review of experiences and analysis of dynamics. International Journal of Water Resources Development, 21(1), 5587.

Lobina, E., \& Hall, D. (2000). Public sector alternatives to water supply and sewerage privatization: case studies. International Journal of Water Resources Development, 16(1), 35-55.

Lynch, Walter (2015). Water Industry Opportunities \& Obstacles. Presentation at the Financial Forum of the National Association of Water Companies. July 15. 
Mack, E. A., \& Wrase, S. (2017). A burgeoning crisis? A nationwide assessment of the geography of water affordability in the United States. PloS one, 12(1)

Mack, E. A., Wrase, S., Dahme, J., Crosby, S. M., Davis, M., Wright, M., \& Muhammad, R. (2020). An Experiment in Making Water Affordable: Philadelphia's Tiered Assistance Program (TAP). JAWRA Journal of the American Water Resources Association, 56(3), 431-449.

Mann, C. L., \& Warner, M. E. (2019). Power Asymmetries and Limits to Eminent Domain: The Case of Missoula Water's Municipalization. Water Alternatives, 12(2), 725-737.

Martins, R., Quintal, C., Cruz, L., \& Barata, E. (2016) Water affordability issues in developed countries - The relevance of micro approaches, Utilities Policy, 43, 117-123 https://doi.org/10.1016/j.jup.2016.04.012.

Megdal, S. (2012). The role of the public and private sectors in water provision in Arizona, USA. Water International, 37(2), 156-168. doi:10.1080/02508060.2012.662732

McDonald, D. A., Spronk, S. J., \& Chavez, D.eds. (2020). Public Water and COVID-19: Dark Clouds and Silver Linings, Municipal Services Project (Kingston), Transnational Institute (Amsterdam) and Latin American Council of Social Sciences (CLASCO) (Buenos Aires).

McDonald, D. A. (2018). Remunicipalization: The future of water services?. Geoforum, 91, 4756.

Megginson, W.L. (2005). The financial economics of privatization. Oxford UK: Oxford Press.

Molinos-Senante, M., \& Sala-Garrido, R. (2015). The impact of privatisation approaches on the productivity growth of the water industry: A case study of Chile. Environmental Science \& Policy, 50, 166-179. doi:10.1016/j.envsci.2015.02.015

NAACP. (2019). Water/Color, A study of race and the affordability crisis in America's cities. New York, NY: Thurgood Marshall Institute at the NAACP Legal Defense and Education Fund, Inc.

Owen, D. L. (2013) Glas Cymru: lessons from nine years as a not-for profit public-private partnership, International Journal of Water Resources Development, 29:3, 343-351, DOI: 10.1080/07900627.2012.721671

Pauli, B. (2020). The Long Road Out of Crisis: (Re)building Trust in Flint's Public Water from Poisoning to Pandemic in Public Water and COVID-19: Dark Clouds and Silver Linings, Municipal Services Project (Kingston), Transnational Institute (Amsterdam) and Latin American Council of Social Sciences (CLASCO) (Buenos Aires).

Pierce, G., El-Khattabi, A. R., Gmoser-Daskalakis, K., \& Chow, N. (2021). Solutions to the problem of drinking water service affordability: A review of the evidence. Wiley Interdisciplinary Reviews: Water, e1522.

Pierce, G., Chow, N., \& DeShazo, J. R. (2020). The case for state-level drinking water affordability programs: Conceptual and empirical evidence from California. Utilities Policy, 63: 101006. https://doi.org/10.1016/j.up.2020.101.006

Renzetti, S., \& Dupont, D. (2003). Ownership and Performance of Water Utilities. Greener Management International 42: 9-19.

Rockowitz, D., Askew-Merwin, C., Sahai, M., Markley, K., Kay, C., Reames, T. (2018). Household Water Security in Metropolitan Detroit: Measuring the Affordability Gap. University of Michigan Policy Solutions, Policy Paper. August.

Rodriguez, R. (2004). The debate on privatization of water utilities: a commentary. International Journal of Water Resources Development, 20(1), 107-112. 
Romano, G., \& Guerrini, A. (2014). The effects of ownership, board size and board composition on the performance of Italian water utilities. https://doi.org/10.1016/j.jup.2014.06.002

Romano, G., Masserini, L., \& Guerrini, A. (2015). Does water utilities' ownership matter in water pricing policy? An analysis of endogenous and environmental determinants of water tariffs in Italy. Water Policy, Vol. 17, No. 5, 918-931.

Rubenstein, E. S. (2000). The untapped potential of water privatization. A Hudson Institute Report for American Water Works.Utilities Policy, 31, 18-28.

Ruester, S., \& Zschille, M. (2010). The impact of governance structure on firm performance: An application to the German water distribution sector. Utilities Policy, 18(3), 154-162. doi:10.1016/j.jup.2010.03.003.

Saal, D. S., \& Parker, D. (2001). Productivity and price performance in the privatized water and sewerage companies of England and Wales. Journal of Regulatory Economics, 20(1), 6190. doi:10.1023/A:1011162214995

Safe water. (2017). Ground water fact sheet. Retrieved from https://www.safewater.org/factsheets-1/2017/1/23/groundwater (accessed March 8, 2021).

Swain, M., McKinney, E., \& Susskind, L. (2020). Water s 5hutoffs in older American cities: causes, extent, and remedies. Journal of Planning Education and Research, 0739456 X20904431.

Tortajada, C., González-Gómez, F., Biswas, A. K., \& García-Rubio, M. A. (Eds.). (2016). The private sector and water pricing in efficient urban water management. Routledge.

Tortajada, C., González-Gómez, F., Biswas, A. K., \& García-Rubio, M. A. (2013). Editorial. International Journal of Water Resources Development, 29(3), 297-299.

Troesken, W., \& Geddes, R. (2003). Municipalizing American Waterworks, 1897-1915. Journal of Law, Economics, and Organization, 19(2), 373-400. doi:10.1093/jleo/ewg015

University of North Carolina. (2015). Report on Federal Funding Trends for Water and Waste water facilities. Retrieved from: http://efc.web.unc.edu/2015/05/14/federal-fundingtrends-for-water-and-wastewater/

United States Drought Monitor (2015). Retrieved from .https://droughtmonitor.unl.edu/Data/DataDownload/ComprehensiveStatistics.aspx (accessed on Jan $1^{\text {st }}$ 2021)

US Census.(2016). American Community Survey. 2016 1-Year Estimates. Retrieved from https://data.census.gov/cedsci/table?q=household\%20size\&tid=ACSST1Y2016.S1101\&h idePreview $=$ false

US Treasury, 2021 Coronavirus State and Local Fiscal Recovery Funds, accessed https://home.treasury.gov/system/files/136/FRF-Interim-Final-Rule.pdf

Wait, I. W., \& Petrie, W. A. (2017). Comparison of water pricing for publicly and privately owned water utilities in the United States. Water International, 42(8), 967-980.

Wallsten, S. \& Kosec, K. (2005). Public or Private Drinking Water? The Effects of Ownership and Benchmark Competition on U.S. Water System Regulatory Compliance and Household Water Expenditures. AEI-Brookings Joint Center Working Paper 05-05. Available at SSRN: https://ssrn.com/abstract=707131 or http://dx.doi.org/10.2139/ssrn.707131https:// papers.ssrn.com/sol3/papers.cfm?abstract_id=707131

Walton, B. (2015). Price of Water 2015: Up 6 percent in 30 major US cities, 40 percent rise since 2010. Circle of Blue, Retrieved from: https://www.circleofblue.org/2015/world/price-ofwater-2015-up-6-percent-in-30-major-u-s-cities-41-percent-rise-since-2010/ 
Warner, M. E., Zhang, X., \& González Rivas, M. (2020). Which states and cities protect residents from water shutoffs in the COVID-19 pandemic? Utilities policy, 67, 101118.

Zetland, D., \& Gasson, C. (2013). A global survey of urban water tariffs: are they sustainable, efficient and fair? International Journal of Water Resources Development, 29(3), 327342.

Appendix 1: Model results without controlling for age of infrastructure and favorable private regulation.

\begin{tabular}{|c|c|c|c|c|}
\hline & \multicolumn{2}{|c|}{ Annual water bill ${ }^{1}$} & \multicolumn{2}{|c|}{$\begin{array}{c}\text { Percent of household income spen } \\
\text { on water (for lowest quintile of } \\
\text { household income) })^{1,2}\end{array}$} \\
\hline & Std. Coeff & Coeff & Std. Coeff & Coeff \\
\hline \multicolumn{5}{|c|}{ Water system characteristics } \\
\hline Service population $(\ln )^{1}$ & -0.057 & -10.299 & $-0.074 *$ & $-0.193 *$ \\
\hline Private sector $^{1}$ & $0.423 * *$ & $174.639^{* *}$ & $0.293 * *$ & $1.744^{* *}$ \\
\hline $\begin{array}{l}\text { PUC regulates public } \\
\text { utilities }^{1,3}\end{array}$ & 0.028 & 16.924 & 0.007 & 0.058 \\
\hline \multicolumn{5}{|l|}{ Water supply } \\
\hline Groundwater $(1=y e s)^{1}$ & $-0.165 * *$ & $-57.347 * *$ & $-0.121 * *$ & $-0.605^{* *}$ \\
\hline Severe Drought $(\%)^{4}$ & $0.185^{* *}$ & $0.635^{* *}$ & 0.009 & 0.000 \\
\hline \multicolumn{5}{|l|}{ Water demand } \\
\hline Gini $^{2}$ & 0.047 & 145.411 & 0.071 & 3.185 \\
\hline Poverty rate ${ }^{2}$ & -0.105 & $-1.878 \mathrm{t}$ & $0.553^{* *}$ & $0.142^{* *}$ \\
\hline Percent of minority ${ }^{2}$ & -0.028 & -0.180 & -0.064 & -0.006 \\
\hline Population density $(\ln )^{2}$ & -0.028 & -3.759 & 0.001 & 0.002 \\
\hline Population growth $(\%)^{2,5}$ & $-0.090 *$ & $-3.125^{*}$ & $-0.084 *$ & $-0.042^{*}$ \\
\hline $\mathrm{N}$ & \multirow{2}{*}{\multicolumn{2}{|c|}{$\begin{array}{c}500 \\
0.2688\end{array}$}} & \multirow{2}{*}{\multicolumn{2}{|c|}{$\begin{array}{c}500 \\
0.4240\end{array}$}} \\
\hline adj. R-sq & & & & \\
\hline
\end{tabular}

$\mathrm{N}=500$ largest water utilities in the US, 2015

Data sources: 1. Our Data Base on Price of 500 Largest Water Systems 2015. 2. American Community Survey 2011-2015. 3. Beecher, 2018. 4. U.S. Drought Monitor 2015. 5. American Community Survey 2007-2011

Note: $* \mathrm{p}<0.05, * * \mathrm{p}<0.0$, OLS regression results 